\title{
Alternative Meanings of Political Reform in Contemporary Thailand
}

\author{
DUNCAN MCCARGO
}

\begin{abstract}
This article argues that constitutionalism is a 'disease' that afflicts Thailand's body politic, reflecting intense contestation among rival elite power-holders. The recent debates concerning political reform in Thailand (which culminated in the promulgation of the 1997 constitution) illustrate this contestation vividly. The vague, positive-sounding term 'political reform' actually means many different things to different people: it is a highly contested concept which has been used to legitimate a variety of political agendas, ranging from progressive ideas; to deeply conservative and even anti-democratic sentiments. The resulting constitution is an excessively long and deeply unsatisfactory document. Nevertheless, it may contain certain details that offer opportunities for the future opening-up of greater political space.
\end{abstract}

\section{Background}

Thailand has had sixteen constitutions since the end of the absolute monarchy in 1932: in other words, the average Thai constitution has lasted just over four years. ${ }^{1}$ Constitution-frequency on this scale (like the coup frequency for which Thailand is also famous) is tantamount to a form of 'permanent constitutionalism', analogous to the Trotskyite notion of 'permanent revolution'. Thailand is one of those countries where constitutions 'are constantly and continually torn up to 
make new ones' (Finer et al. 1995: 2). Whereas in some countries the constitution is often treated with a kind of exalted reverence which borders on the mystical (the US being the most conspicuous example), in Thailand the constitution has often been a central space for contesting day-to-day political realities. Each new shift in power, whether initiated by a military coup or reflecting a rise in civilian influence, is marked by a new constitution, a new high watermark which illustrates the constantly shifting political tides. Whereas a constitution for many other countries is something above the fray of day-to-day politics, a document treated with considerable respect and tampered with only in extremis, the Thai constitution is a political football to be kicked around by the winning team. Changing the constitution is a relatively mundane matter, the predictable outcome of a shift in power. As Chai-Anan Samudavanija - one of Thailand's most dedicated students and practitioners of constitutionalism-has observed, amending the constitution is part of a 'vicious cycle' of constant but ultimately static political change (Chai-Anan 1982: 1-3). A military coup is followed by a revision of the constitution, elections are then held, but a political crisis develops which precipitates a further coup, and so on. A new power elite seeks to legitimate its rule by imposing a new constitution; yet that constitution itself becomes the basis for a new round of political contestation, which in turn brings about abrogation or revision of the constitution.

In practice, constitutionalism has undergone various phases in the post-1932 period. The first phase was ushered in with the promulgation of the second constitution in December 1932, which set the tone for subsequent constitutions over the next twenty-six years: parliament was to be firmly subordinated to the power of the executive (Wilson 1967: 16). A second phase began after Field Marshal Sarit seized power in 1958: the 1959 interim constitution remained in effect for a decade, and parliamentary politics were suspended. A third phase arguably started with the promulgation of the 1968 constitution, which marked the beginning of a limited opening up of the political 
order. When the Thanom regime to sought to reverse that opening up by suspending parliament and introducing the more authoritarian 1972 constitution, the scene was set for the popular uprising of October 1973. Since 1973, constitutionalism has been more than a fact of Thai political life; it has become a way of life for political actors in Thailand. One of the issues underlying the bloody 1992 May events in Bangkok was disagreement about constitutional changes. The abuse or mishandling of the constitution-drafting process by elites can provoke popular discontent, mass protests and even bloodshed.

Often seen as a cure for the country's political ills, constitutionalism could also be seen as a political 'disease' that paralyses and distorts Thai public life. Preoccupations with constitutional revision can feed the ambitions of academics, lawyers and superannuated senators. These professional constitution drafters appear to hanker after the creation of a 'real' Thai constitution, which, unlike all previous Thai constitutions, will be fail-safe, foolproof, cast-iron, lasting and eternal. Those who succeed in creating the immortal 'real' constitution will go down in history as Thailand's Thomas Jeffersons. The myth of the real Thai constitution, like the chimera of the real Thai political party (McCargo 1997b: 114-31), may be seen as a mirage.

Chai-Anan Samudavanija himself is perhaps the ultimate professional constitution drafter, proud of his role in formulating the 1974 constitution (see Chai-Anan 1990 for details of how he came to this task as an 'academic greenhorn'). Like many of his fellow 'professional' constitutionalists, Chai-Anan did graduate work in the US, and appears to have imbibed a quasi-American reverence for the constitution from this experience. The American passion for the constitution reflects a number of historical facts. The US constitution emerged from a bitter revolutionary struggle, from a rejection of the British government and monarchy, and from the lack of any long historical tradition (Finer et al. 1995: 7-8). In the absence of other national monuments, the Americans created a written one, a set of stone tablets which gave substance and meaning to their 
emergent nation. For most Europeans, the American attachment to the constitution is faintly comical, testifying to fundamental insecurities of national history and identity. For the Thai elite to emulate the American pattern is perhaps somewhat surprising, given the long history of Siam, the existence of a constitutional monarchy, and lack of any major independence movement or revolutionary struggle. Arguably, the Thai preoccupation with constitutionalism reflects a recurrent desire to establish firmer foundations for the relatively shaky political order that replaced the absolute monarchy. By merely replacing one oligarchy with another (Girling 1981: 60), the 1932 changes left Siam (and later Thailand) with a good deal of unfinished political business.

Despite the ironies and paradoxes that pervade much Thai constitutionalism, the constitution-drafting process can sometimes take on a life of its own, influencing the political process in unexpected ways, and inadvertently allowing rays of progressive light to penetrate Thailand's dark caves of legalism and muddle-headedness. In February 1991, a military coup ousted elected Prime Minister Chatichai Choonhavan. The coup group, known as the National Peace Keeping Council (NPKC), immediately abrogated the constitution and established a committee to draft a new one. By packing the committee, and leaning on its members, the NPKC ensured that the end product pleased almost no one. In particular, one clause allowed for the possibility that a non-MP could become Prime Minister. The constitution-drafting process mobilised considerable forces, both enlisting academics and others sympathetic to the military and co-opting them by enrolling them into the drafting committee, and also by offering a focus for political dissent which was directed at the drafting process rather than the coup group itself. The political movement generated by the constitution-drafting process culminated in the largest political rally to be held in Thailand since 1976, a gathering of over 50,000 protesters held at the Sanam Luang in November 1991 (see McCargo 1997d: 240-41). 
The following month, the unsatisfactory draft constitution was passed anyway. As Hewison has noted, Thailand's constitutional monarch, King Bhumiphol, has often shown a lack of enthusiasm for the 'foreign' ideas of constitutionalism (Hewison 1997: 68-73), and declared that although the 1991 constitution was 'not ... fully adequate', it could always be amended later on (Hewison 1997: 70). But the inadequacy of the new constitution gave the green light for coup leader General Suchinda Kraprayoon to exploit the provision for an unelected Premier to become Prime Minister in April 1992-a move which precipitated mass demonstrations, the use of lethal force against civilians, scores of deaths, and the political crisis known as the May events (for accounts, see Callahan 1998; McCargo 1997d: 240-74; Physicians for Human Rights 1992). A constitution-drafting process which was intended to consolidate the NPKC's grip on power, to co-opt sympathetic elites, and to divert political dissent away from the coup group, wholly failed to achieve its objective. The constitution-drafting directly precipitated a new crisis which undermined the objectives of the military coup itself.

Constitutional change, far from being concerned with reforming or overhauling Thailand's political order, has more generally been associated with consolidating the elite's monopoly on power, and diverting potentially dissident intellectuals and critics down culs-de-sac of committee meetings. The preoccupation with revising the constitution, which has long tormented the Thai elite, reflects fundamental insecurities about the purpose and direction of the Thai political order; more importantly, it reflects a continuing concern with the legitimation of power. Nevertheless, to revise the constitution is to open up a kind of political space, a veritable Pandora's box of competing interests and demands. As Thai politics becomes increasingly pluralistic (not increasingly democratic; see McCargo 1997c), the demands of different interest groups for a share of the constitution-drafting cake become more vocal. As the capacity of state elites to control the political agenda becomes increasingly undermined by a rise in pluralism, and by the erosion of state 
capacity associated with the globalisation of the economy, so the potential for reformist life to spring forth during the constitution-drafting process becomes greater, despite the best intentions of the ruling elites and their comrades-in-arms, the professional constitution drafters. The political reform movement of 1994-97, which culminated in the promulgation of a new constitution in November 1997, reflected a high degree of contestation among different interest groups, whose agendas ranged from the deeply conservative to the highly progressive.

\section{The need for reform}

By 1997, there could be little doubt that the Thai political order was in need of substantive reform. At the heart of the problem was a crisis of confidence in electoral politics. The rise of votebuying and other forms of electoral corruption (see Callahan and McCargo 1996; Sombat 1993) meant that the electoral process was becoming increasingly exclusionary, controlled by an unholy alliance of so-called 'professional politicians', provincial crooks and hoodlums, unsavoury business interests, large companies, and third-rate ex-soldiers and bureaucrats (Surin and McCargo 1997). These groups had been beneficiaries of the 'inadequate' 1991 constitutional arrangements, under which they had thrived and flourished. At the same time, the reasons for the shambolic state of electoral politics-which produced such inept Prime Ministers as Banharn Silpa-archa and Chavalit Yongchaiyudh, and meant that even a more plausible Premier such as Chuan Leekpai had to keep the likes of Suthep Theuksuban $^{2}$ in his cabinet-went much deeper than mere questions of constitutional arrangements and electoral laws, and resulted from the nature of Thailand's political economy in the 1990s. The criminal and semi-criminal elements so over-represented in the Thai parliament had benefited immeasurably from Thailand's boom economy during the late 1980s and early 1990s, creaming off many of the benefits of economic growth for themselves and for their supporters. Although legal changes 
might have some marginal effect on their influence, forcing them to adopt different strategies in seeking elections, technical revisions of the constitution and associated laws would not be sufficient to legislate these groups out of office.

\section{Events leading to the 1997 constitutional reform}

The conflict between the National Peace Keeping Council and other political forces during the February 1991-May 1992 period had been symbolised by a series of disputes over the nature of the Thai constitution. Central issues included the question of whether a non-MP could be Prime Minister (fine if the non-MP were Anand, unacceptable if he were Suchinda), and the relative powers of the elected lower house and the appointed Senate. As Kusuma Snitwongse noted (Kusuma 1995: 194):

It was to be expected that the 'angelic' coalition government led by Prime Minister Chuan would take the lead in amending the Constitution to bring about a truly functioning democratic system.

This expectation was not to be realised. Opposition parties, senators, and the New Aspiration Party (then a member of the government coalition) sought to block progressive amendment of the constitution. Chuan himself, essentially a conservative whose primary preoccupation was retaining power even if this meant treading water on important political issues, was not wholeheartedly committed to forcing through amendments. But his administration came under sustained pressure to do so from the Palang Dharma Party, and from extra-parliamentary forces which had been associated with the anti-military protests of the May 1992 events.

At the height of a tense political stand-off over constitutional reform in June 1994, precipitated by the hunger strike of prominent activist Chalard Vorachat, the Democrats set up the Democratic Development Committee (DDC) to draw up a set of proposals for far-reaching political reforms. The committee was 
chaired by Dr Prawes Wasi, a medical practitioner with close links to the NGO community. Prawes's considerable achievements (he had won a Magsaysay prize in the 1970s), his impressive range of connections, and his reputation for great integrity, have made him a kind of non-partisan elder statesman in Thai society. Early in 1995, the DDC unveiled its proposals; these involved an elaborate parliamentary system which would have three main components, and would separate legislative from executive functions so that MPs could not hold ministerial office (for details, see Democratic Development Committee 1995 and Prawes 1995). By the time the DDC presented its report, political conditions had greatly changed. The Democrat administration was fighting for its very survival over a huge land reform scandal. The DDC's proposals were generally regarded as idealistic and unworkable (Democrat politician Abhisit Vejjajiva memorably remarked that he would support any plan for political reform except the DDC's proposal), and were largely forgotten when the Chuan government collapsed following a no-confidence debate in May 1995.

Although the specific proposals of the DDC quickly fell by the wayside, the general question of reforming the political system remained very much a live issue, and Prawes himself saw the promulgation of the 1997 constitution as a direct outcome of the DDC's work. Dr Prawes's cure was much-disputed, but his diagnosis was widely accepted. He had identified eight basic problems in the Thai political system which were in urgent need of reform (Prawes 1995: 3):

- The dominance of money

- The monopolisation of politics by a minority

- The difficulties faced by good and able people in entering politics

- Dishonest and improper behaviour

- Parliamentary dictatorship

- Political conflict and instability

- Poor quality of administrative and legislative functions

- Lack of political leadership 
Although the clamour for political reform might seem to have signified demands for greater democracy, this was not necessarily the case for all those urging reform. Political reform was an intensely contested concept. Demands for political reform reflected the desire of competing groups in Thai society to renegotiate (and so enhance) their political power. Reform could be attractive to the military if it reduced the power of elected politicians; similarly, political reform could appeal to the Bangkok business community if it offered to reduce the influence of provincial business people. Prawes was right to point out that the parliamentary system concentrated power in the hands of a minority: but which minority could not be trusted with power? His reference to 'good and capable' people who found difficulty in getting elected suggested that there might be a group of virtuous technocrats well qualified to administer the country, perhaps comprising people like Anand Panyarachun. ${ }^{3}$ Political conflict and instability might seem to be undesirable, but would a more stable, more repressive and more authoritarian order be more desirable? Clearly, some groups might prefer a more authoritarian order, and others would not. Noticeably absent from Prawes's eight points was any explicit reference to the need for more effective representative government, which would respond better to popular demands. Political reform meant different things to different groups, and could easily focus upon mechanisms for managing elite conflict, rather than devolving power to the grassroots level. Some of the alternative meanings of political reform are examined below.

\section{Alternative meanings of political reform}

\section{First step in a major programme of reforms, to include the bureaucracy and the education system}

This meaning of political reform was sufficiently broad to allow for alliances between conservatives and radicals. For Prawes himself (who might best be termed a 'radical conservative'), 
political reform was the cornerstone of a large-scale package of measures to transform the state and society in Thailand. Prawes had little interest in the legal minutiae which animated many of the professional constitution writers with whom he was obliged to form a pragmatic alliance. His main preoccupation was in generating the momentum for changes which would lead to the comprehensive reforms in the bureaucracy and the education system, sweeping away the extraordinary over-centralisation which was such a debilitating feature of Thai public life. What distinguished Prawes from other reformers was the breadth of his vision, and his lack of conventional personal ambition. Alongside the political reform campaign, he worked on issues of social partnership and community building, as well as on other areas of public sector reform. One of his preoccupations was the strengthening of Thailand's research base through a programme of support for Thai academics. Whilst on the one hand seeking to create a more rational political and social order, he also shamelessly exploited his own extensive personal contacts to initiate and pursue his projects: in other words, rational goals were sometimes pursued by using paternalistic and clientelist methods.

Many figures with a more progressive political perspective than Prawes were in sympathy with his calls for a drastic overhaul of the existing order, and especially for an attack on the powers and privileges of the bureaucracy. As a member of the elite who sympathised (but arguably never fully empathised) with the needs of poor people, Prawes played a bridging role between the political order and the non-governmental sector. It is interesting that Prawes saw the 1997 constitution as an outcome of the DDC's work, despite the fact that few of the DDC's detailed proposals were incorporated into the new constitution. ${ }^{4}$ Just as for the King, one constitution often seemed as good as another, for Prawes virtually any political reform was a positive step; the core objective was to build up a momentum for change. 


\section{A conservative (and royalist) project to prevent violent social disorder}

Dr Prawes had been arguing for some time that there was considerable potential for violent conflict to break out once again in Thai society. He saw three possible causes for such an outbreak: the frustrations of people in rural areas, a crisis of confidence in the political system, and a third cause, about which he did not elaborate. ${ }^{5}$ At a seminar on 2 November 1995 at the Siam Inter-Continental Hotel in Bangkok, he hinted at the explanation when he declared that people did not want to think about what they would do when the King died. Whom would they look to for solutions to pressing problems such as traffic and flooding? ${ }^{6}$ This was an extraordinary public statement by Prawes: speculation about possible scenarios following the death of King Bhumiphol is widespread in private, but never aired from a conference platform. Many analysts privately fear that the next monarch may lack King Bhumiphol's high level of popular legitimacy (accrued during fifty years on the throne), and may be unable to make effective interventions at times of intense political conflict. As an ardent royalist, Prawes saw the monarchy as a central part of the solution, rather than as part of the problem itself. Prawes's very clear and public suggestion that Thailand might face a potentially violent crisis on the death of the King was unprecedented.

Needless to say, the point was not mentioned in subsequent press reports of the speech, and other speakers and questioners from the floor failed to follow up on the issue. As a doctor affiliated with Siriraj Hospital (where the King and other members of the royal family received all their medical treatment) and a respected senior figure with close personal connections to the palace, Prawes may have felt that he was able to make more explicit statements about the succession problem than any other individual in Thai public life. At the same seminar, he argued that even if the DDC proposals were not being implemented at present, they offered a useful 'way out' in the event of a major political crisis. It was clear that Prawes was expecting just such a crisis any time soon. Although Prawes himself 
saw reform of the political system as simply the first step in a sweeping programme of reforms which would also include the bureaucracy and the education system, it was also possible to regard the whole discourse of political reform as a conservative (and royalist) project to prevent violent social disorder. Political reform might therefore have two core objectives: to stabilise the political system, thereby reducing the potential for severe crises which in the past (October 1973, October 1976, April 1981, May 1992) had involved royal interventions; and to protect the institution of the monarchy itself from the threat posed by violent instability (such as the instability triggered by a succession crisis). The more robust the political system, the less likely it was that the monarchy could become a casualty of severe political crisis. For Prawes, one goal of political reform was the creation of a crisis-proof monarchy.

\section{A means of pre-emptive crisis management}

On one level political reform was about pre-emptive crisis management: putting the right structures in place to cope with stresses caused by impending socio-economic and political upheavals. Prawes argued that he was very reluctant to chair the Democratic Development Committee when asked to do so in 1994 by the then President of parliament Marut Bunnag. ${ }^{7} \mathrm{He}$ knew that he would be criticised by the media (which he saw as hostile to the Chuan government, and indeed to all governments), but his main objective was to avert violence, and to help find a way out of the stand-off which would not result in the death of Chalard and consequent escalation of the political temperature. Yet it also seems likely that the offer from Marut to chair the DDC, although in many respects a poisoned chalice, offered Prawes an opportunity to pursue his own larger objectives of a long-term quest for political stability. One of his ultimate goals was the creation of nonviolent mechanisms for managing and transferring power. The strength and weakness of Prawes's goal of pre-emptive crisis management, was that this goal was shared by the very same conservative bureaucrats whose power Prawes was hoping to undermine through his 
reformist programmes. Whilst Prawes was undoubtedly sincere in his talk of the need to avoid violence, the repeated invocation of potential violence as a rationale for pursuing political reform had the effect of concentrating wonderfully the minds of bureaucrats, military officers and capital controllers, both domestic and international. Indeed, the DDC itself was created precisely to head off an impending crisis over the 1994 Chalard hunger strike. Prawes demonstrated formidable political skills by using the vehicle of a committee that had been created to sideline a key issue, in order to keep that issue alive and build a broad coalition for political reform. Yet the need to build this kind of broad coalition also had the effect of watering down the details of the political reforms that were eventually incorporated in the 1997 constitution.

\section{A project by elite conservatives to check the power of elected politicians}

For some elite conservatives who paid lip-service to the cause of political reform, the process of reforming the political order reflected attempts to check the power of elected politicianspower which some bureaucrats saw as illegitimate. Military officers had long been more or less openly contemptuous of the antics of elected politicians, and many civilian bureaucrats shared similar views. They believed that the rise in power of political parties and elected politicians had seriously undermined their own influence and standing. 'Parliamentary dictatorship' - one of the eight points Prawes cited as in need of reform-had also been one of the five key justifications given by the 1991 military junta for their seizure of power. Senior figures such as Anand Panyarachun had never concealed their distaste for the cut-and-thrust of electoral politics, with its culture of vote-buying, sleazy coalition-building, and dealmaking (see Anand 1994). Many supporters of political reform were in fact primarily interested in electoral reform, developing mechanisms for curtailing the illicit manipulation of the electoral process. Although in many respects these criticisms of electoral politics were highly justified, the motives of some 
critics need to be closely scrutinised: how far did these critics want to create a cleaner, more representative electoral politics? And how far did they wish to undermine the credibility of electoral politics, positing the implicit alternative of rule by a cabinet of unelected technocrats, backed by the monarchy or the military (the model of the much-praised Anand 1 and Anand 2 governments)?

Given that elected politicians were one of the principal targets of political reform, their own stance on the issues at stake was often ambiguous. Politicians who were major beneficiaries of the existing system had little to gain from reforming it; their support for reforms was typically highly selective and tentative. Although many politicians were reluctant openly to denounce calls for reform (thereby laying themselves open to the charge of obstructionism and self-interest), the majority sought to stall or subvert the reform process using whatever mechanisms they could. The politicians who demonstrated the greatest enthusiasm for reform were typically those from Bangkok constituencies (where vote-buying and electoral corruption, though common, were not usually decisive in determining political outcomes), or those with strong local followings in their home constituencies, who could be confident of reelection under almost any reformed system.

\section{A means of reducing the influence of provincial business people}

In part, the interest of Bangkok voters in political reform reflected their reluctance to be ruled by politicians whom they regarded as regionalist (Chuan, Chavalit) or provincial (Banharn) in outlook. A cynical view is that at the core of Bangkokians' demands for political reform was a desire for elected representatives sympathetic to the needs of an urbandominated society. For 'central' Bangkok Thais-themselves a minority with only 10 per cent of parliamentary seats under their control-political reform offered a means to reduce the reality of domination by what they regard as the periphery. At the same time, whilst most Thai politicians gained their power 
in the provinces (from elections outside Bangkok), they exercised that power in the capital. Despite the electoral dominance of the provinces, there had been no sustained shift in resources beyond Bangkok during the 1980s and 1990s; substantive decentralisation (which would include relocating some ministries and corporate headquarters to provincial cities) was not on the agenda. But there was certainly a considerable divide between the MPs elected in Bangkok (the majority of them respectable, educated people from parties such as the Democrats or Palang Dharma), and provincial MPs with their criminal connections and questionable backgrounds. Nevertheless, genuine reform of the political order, which might have allowed articulate and sophisticated advocates of voters' interests from the regions to gain power and influence, was not in the interests of the Bangkok elite. The prevailing system of 'incompetent' and 'tainted' provincial politicians, who were forced to share power with technocrat ministers and 'acceptable' allies, was a system which in some respects suited the purposes of the Bangkok elite, who reaped certain benefits from the discredited and indefensible political order. Whilst many advocates of political reform sought to marginalise sleazy provincial power-brokers, few were altruistic enough to countenance the systematic empowerment of ordinary provincial people.

The metropolitan business sector, which was more international and transparent in its dealings than its provincial counterpart, saw political reform as a means by which a wider range of business opportunities could be made available, curtailing the wheeler-dealing of rural machine politicians and their crony contractors, and thereby opening up a wider range of markets for their goods and services (Anand 1994: 7). Nevertheless, metropolitan business was by no means as reputable and transparent as it wished to pretend. The economic crisis which began in July 1997 revealed the extent to which wellknown figures in the Thai business community had engaged in dubious or disreputable dealings. 


\section{A means of allowing 'virtuous' technocrats to administer the country}

For some conservatives, the rhetoric of political reform offered a convenient vehicle for an attempt to inaugurate a 'technocratic polity', a more sophisticated, more globalised, and more responsive version of the 'bureaucratic polity' of the 1950s and 1960s (see Riggs 1966); yet nevertheless a political system which was elite-dominated, and deeply subservient to the needs of capital, both domestic and international, perhaps somewhat resembling that of Singapore. A Singapore-style technocratic state would satisfy all the eight points identified in Prawes's diagnosis of Thailand's political ills: the dominance of money would be removed (by a 'cleaned up' electoral system); politics would no longer be monopolised by a minority (instead, technocrats would rule on behalf of the majority); dishonest and corrupt behaviour would be purged; parliamentary dictatorship would be ended (parliament would become a sideshow controlled by the executive); political conflict and instability would be removed; administrative and legislative functions would be carried out very effectively; and effective political leadership would be installed. The model for such a polity was the Anand 1 and Anand 2 governments, which had seen high-calibre technocrats run the country without benefit of parliament or elections. These governments were often praised as the best Thailand had ever had. Such a technocratic polity would not simply clean up electoral politics, but would effectively by-pass such politics altogether.

Much of the discussion along these lines centred upon means of separating the functions and duties of the legislature from the executive; in other words, to devise ways of preventing elected MPs from claiming ministerial positions. At the core of these proposals was a desire to ensure that real power lay in the hands of 'qualified' individuals (people sympathetic to the interests of capital controllers and other elites, typically including retired bureaucrats with a 'clean' image, along with Western-educated business people and economists), reducing elected representatives to minor roles such as answering con- 
stituents' letters and revising legislation (legislation has never had much importance in the Thai political order, since most decisions are made by cabinet decree). Although it was undoubtedly the case that many elected politicians were unqualified for ministerial office, the hostility to elected politicians coming from some conservative 'reformers' reflected a desire to reverse some recent democratic 'gains', and concentrate power in the hands of a small, self-selecting elite. A variety of different elites were willing to co-operate for the purposes of marginalising elected politicians; the precise composition of the technocracy would itself be the outcome of political contestation between rival power groups (for example, military versus civilian, and private versus public sector).

\section{A way of devolving power to the grassroots level}

Another component in the political reform movement was the sector aligned with non-governmental organisations (NGOs) and people's organisations (POs). This sector was deeply disappointed with the failure of the political order to address popular grievances such as economic inequality and poor legal rights. Why did a political system dominated by rural-based parties and politicians deliver so little to the rural voters who elected them? NGO and PO groups sought political reforms that would undermine the existing elite-dominated structures, and empower villagers and people at the grassroots level, inverting the hierarchical pyramid of Thailand's state and society (see Naruemon 1997). Some of their input into the political reform process was based upon their experience of working with the election-monitoring body Pollwatch (Ongkorn Klang) during the five 1992-97 general elections. Pollwatch Secretary-General Gothom Ariya was one of the leading figures in this group. Despite (or because of) their commitment and expertise, groups seeking to influence political reform in order to devolve more power to the grassroots were regarded with deep suspicion by most other participants in the political reform process, especially by the Ministry of Interior. The Ministry of Interior-a vast bureaucracy respon- 
sible both for administering Thailand's provinces in a topdown, colonial-style fashion, and for controlling the electoral process on the ground-had as its core objective the defence of the status quo. In the debate over political reform, the Ministry of Interior mobilised a range of forces, from organised groups of village headmen to sympathetic senators and academics, in order to resist the inclusion of decentralising principles within any political reform package. Even within the non-governmental sector, there were wide differences of opinion: some NGOs took a broadly conservative, top-down view, in contrast with the radical and critical perspectives expressed by grassroots PO networks such as Forum of the Poor and the Small Scale Farmers' Federation of the Northeast.

\section{The prelude to redrafting}

Throughout the 1995 election campaign, politicians of all parties were pressed by the media on their plans for political reform. Chart Thai leader Banharn Silpa-archa, acting on advice from close aides, grasped the nettle by proclaiming his commitment to a thorough overhaul of the political system. Implausible though this pledge appeared coming from an old-style rural machine politician, it gave Chart Thai an edge over the Democrats which was to prove crucial. On assuming the premiership in July 1995, Banharn established the Political Reform Committee (PRC), chaired by his ex-political scientist brother Chumphol. Little was heard about political reform from Banharn thereafter, but the issue remained a topic of popular debate, sustained by the media and a low-key but persistent campaign by Dr Prawes and other social critics (see McCargo 1997a: 37-39). The print media played an important role in demands for political reform from 1995 to 1997. One regular venue for such campaigning was the Phujatkarn Daily newspaper, and especially the regular columns of Chai-Anan Samudavanija, Kasian Techapira, and Khamnoon Sitthisaman, who wrote some of his columns under the pen name 'Rambutri 
516 '. Critics of what might be termed the 'Phujatkarn school' of political reform argue that the columns sometimes had a repetitive, self-important quality. But support for political reform from Phujatkarn, and from other serious newspapers such as Siam Post and The Nation, helped sustain the pressure on the Chuan, Banharn and Chavalit governments to initiate constitutional change. Similar demands were reflected in the electronic media, and were echoed by numerous academics and social critics in the panel discussions which are such a salient feature of Thai intellectual life.

In late 1996, progress was made towards the goal of constitutional reform when a compromise was struck concerning the composition of a new Constitution Drafting Assembly (CDA). The ninety-nine members of the Assembly were selected from two sources: seventy-six were indirectly elected provincial representatives (one per province), while twenty-three were experts in political science, law, politics and public administration (the 'professional constitution drafters'). Despite a complex nomination process, the final selection of CDA members was made by parliament. Prior to the elections for the CDA, one newspaper published a list of 'government-approved' candidates, which closely resembled the final composition of the CDA. Nearly a quarter of CDA members were ex-MPs, whilst there were also numerous lawyers and retired bureaucrats. The CDA was an essentially conservative, government-approved body.

\section{Drafting procedures for the 1997 constitution}

An elaborate drafting process was devised for the 1997 constitution, one that went through the motions of broad consultation, but actually reflected a largely top-down process (for details, see Ockey 1997: 313-15). A constitution-drafting committee prepared a detailed draft which was then submitted to the ninety-nine-member Constitution Drafting Assembly (CDA) for approval. Once a draft had been approved by the 
CDA, a process of public consultation took place on a nationwide basis, co-ordinated by the public relations committee. Public hearings were held, and input solicited. In this respect, the 1997 constitution-drafting process was characterised by a much more open spirit of debate than any previous drafting process, with the honourable exception of 1974 . The constitution-drafting committee finalised a draft; this was checked and approved by the CDA, which then submitted it to parliament. Parliament was not given the option of amending the draft, but was obliged either to ratify or to reject it. Had parliament failed to approve the draft, a nation-wide referendum was to have been held to determine whether or not the new constitution should be adopted. One strong point of the process was its use of fixed deadlines for each stage of the drafting; the pressure to meet these deadlines built up a powerful momentum, which was ultimately almost impossible for the government to control.

Whilst the constitution-drafting process went through the motions of public consultation by making use of an 'elected' CDA, and by sounding out public opinion during the 'public hearing' phase, the fact was that the process remained heavily elite-dominated. Dr Prawes criticised the lack of genuine public participation in the constitution-drafting process, and expressed the fear that there might be more violent demonstrations in the future if the charter did not reflect popular wishes (Bangkok Post 'Constitution special', 27 March 1997). Symptomatic of the tokenistic character of the public consultation was the provision that voters would only participate in a referendum on the constitution if the draft were first rejected by parliament. A popular referendum to approve or reject the constitution (as staged in the Philippines in 1987) would have been a real milestone in increased popular participation in Thailand.

The constitution-drafting process also was a source of vast quantities of patronage. Members of the various committees and of the CDA itself received generous meeting allowances and other perks, while the public relations committee dispersed a huge budget to organisations all over the country, for the 
rather vague task of promoting popular awareness of the constitution-drafting process. Those involved in the constitutiondrafting process were able to engage in considerable self-promotion, giving interviews to the press and electronic media and making other public appearances. For many of those involved, membership of the CDA or one of the various committees was an important means of launching, sustaining, or relaunching a career as a politician or public intellectual.

In the event, the economic crisis which engulfed Thailand following the de facto devaluation of the baht in July 1997 overshadowed the constitution-drafting process. The Thai government spent much of August 1997 locked in negotiations with the IMF, trying to bail the country out of its desperate financial plight. Although some politicians tried to block parliamentary approval of the draft constitution (notably the powerful Interior Minister and New Aspiration Party Secretary-General Sanoh Tienthong), Prime Minister Chavalit Yongchaiyudh recognised that parliamentary rejection of the draft would only serve further to undermine his precarious political standing. Despite the advice of certain key lieutenants such as Sanoh, Chavalit reluctantly backed the draft constitution, which was passed by a large parliamentary majority. Thus the need for an expensive and complex referendum process was averted; the politicians were able to save their resources for the next general election, which they feared might come soon. In the event, the passage of the constitution could not save Chavalit, and in November 1997 his government was replaced by a new coalition led by former Premier Chuan Leekpai, a coalition that had emerged without the holding of a new election.

The new constitution, which came into effect in November 1997, was a lengthy document of questionable quality (Thai Constitution 1997). It contained no less than 336 articles, as compared with the 7 articles of the US constitution, and the 103 articles of the Japanese constitution. Many of the points in the new Thai constitution (for example, attendance requirements for senators, qualifications of voters, the requirement to pay taxes) were matters covered by conventional legislation in other 
states. In part, the constitution reflected the weakness of the legislature and the paucity of other legislation: laws that had no business being included in the constitution at all were inserted into it, since otherwise they might never be enacted at all. This was precisely the danger which King Bhumiphol had urged the members of the CDA to avoid, in his remarks to them on 18 January 1997 (Royal Remarks, n.d.: 42):

... if you make it too detailed, it will be difficult to draft a proper constitution because, in fact, a constitution is a law that is the "mother of all laws", or is a law that lays down the foundations for the various rules governing the country.

Members of the drafting committee fought to insert pet themes and favourite details from previous constitutions into the 1997 constitution, and thereby produced a catch-all document with a rambling, miscellaneous character. For many of those involved in drafting the constitution, this was their sole opportunity to introduce legal reforms. The excessive specificity of the constitution meant that it was unlikely to stand the test of time.

John Girling, writing of the 1932-80 period, described Thai 'constitutions' (he puts the word in inverted commas) as 'repeated, but vain, attempts to find a solution' to the lack of legitimacy enjoyed by successive regimes. He notes that these attempts had proved uninspiring (Girling 1981: 151). Similar observations could be made about the 1997 constitution, which contained a hotchpotch of different measures, and reflected a variety of compromises between competing interest groups. Nevertheless, the process of drafting the new constitution did generate a momentum which a weak government and shambolic parliament found impossible fully to resist or control, testifying to the disorderly pluralism of Thailand's multiple elites.

The new constitution did contain a number of interesting electoral reforms, notably the rule preventing politicians from switching parties less than 90 days before an election (designed to prevent the horse-trading of electable candidates which had come to precede every Thai general election campaign), and the 
switch from multi-member constituencies to a combination of a 'party slate' proportional representation system, plus singlemember constituencies. Although these changes might undermine existing patterns of vote-buying and electoral corruption, many analysts feared that politicians would soon find ways of circumventing the measures, changing the rules but continuing to play a broadly similar game. Indeed, the general election that followed a political reform bill introduced in Japan in 1994 (with the same combination of proportional representation and single-seat constituencies) produced a parliament containing almost exactly the same faces as the former system of multimember constituencies. In some respects, the most interesting reforms of the new constitution lay not in the probably doomed attempts to transform the nature of electoral politics, but in provisions that permitted citizens to challenge the power of the state, such as Article 56, which gave people the right to sue the government or state agencies for harming the environment. Although most of these provisions were (doubtless deliberately) vaguely worded, they could form the basis for legal and other challenges to abuses of power, thereby offering increased room for manoeuvre by NGOs and community activists.

\section{Conclusion}

Constitutional reform has a long and dubious history in Thailand. The 1997 constitutional reform process illustrated many of the worst features of that history: questionable objectives, elite dominance, high-level squabbling, parliamentary ineptitude, self-interested drafting bodies, and a badly written final product. There are ample grounds for regarding the preoccupation with constitutional reform, which characterises many sections of the Thai elite, as a kind of terminal political malaise.

The positive results which have emerged from the process are often largely unintended by the main sponsors of reform; for example, the 1991 constitution revision process helped 
spawn an organised opposition to the National Peace Keeping Council, which later culminated in the ouster of General Suchinda from the premiership in May 1992. Similarly, as part of the trade-offs done to hustle through the 1997 constitution, a few progressive articles were allowed to remain in the final version, articles which may help sow the seeds for future agitation and social change. The open character of public debate in Thailand by the late 1990 s certainly represented a dramatic improvement on the political conditions of the 1960s and 1970s. To borrow the King's words about the 1991 constitution, the 1997 constitution is 'not fully adequate', and is unlikely to stand the test of time. However, the transience of most Thai constitutions is testimony to the pace of political life in Thailand, and to the ever-present potential for dynamism and change.

Duncan McCargo is Lecturer in Politics at the Department of Politics, University of Leeds, Leeds LS2 9JT, UK; phone +44 113 233 6865; fax +44 113233 4400; e-mail d.j.mccargo@leeds.ac.uk He is the author of Chamlong Srimuang and the New Thai Politics (London: Hurst 1997), and currently holds an ESRC fellowship to study the media and politics in Thailand and Pacific Asia.

\section{Notes}

${ }^{1}$ There are various competing lists of Thai constitutions in circulation; the most accurate appears to be Vichai 1997: 60-63, which lists sixteen as follows: 1932 (June), 1932 (December), 1946, 1947, 1949, 1952, 1959, 1968, 1972, 1974, 1976, 1977, 1978, 1991 (March), 1991 (December), and 1997.

${ }^{2}$ Suthep, an influential Democrat Party MP and power broker from the Southern province of Nakhon Si Thammarat, was at the centre of a land reform scandal which led to the demise of the 1992-95 Chuan government. Nevertheless, at the start of his second term as Prime Minister in November 1997, Chuan Leekpai appointed Suthep to the powerful and potentially lucrative post of Minister of Communications. 
${ }^{3}$ Anand, a respected former diplomat and business leader, served two terms as an unelected Prime Minister in 1991 and 1992.

${ }^{4}$ Interview with Dr Prawes Wasi, 6 August 1998.

${ }^{5}$ Interview with Dr Prawes Wasi, 13 November 1995.

${ }^{6}$ Author's fieldnotes, 2 November 1995.

${ }^{7}$ Interview with Dr Prawes Wasi, 13 November 1995.

\section{References}

Anand Panyarachun 1994. 'Implications of rapid economic growth for Thailand's political structure'. South East Asia Research, 2, 1: 5-11.

Callahan, William A. 1998. Imagining Democracy: Reading 'the Events of May' in Thailand. Singapore: Institute of Southeast Asian Studies.

Callahan, William A. and Duncan McCargo 1996. 'Vote-buying in Thailand's Northeast: the July 1995 general election'. Asian Survey, 36, 2: 376-92.

Chai-Anan Samudavanija 1982. The Thai Young Turks. Singapore: Institute of Southeast Asian Studies, 1982.

Chai-Anan Samudavanija 1990. 'Educating Thai democracy'. Journal of Democracy, 1 (4): 10415.

Democratic Development Committee (DDC) 1995. Conceptual Framework for Reforming Thai Politics. Bangkok: Thailand Research Fund, April. (In Thai)

Finer, S. E., Vernon Bogdanor, and Bernard Rudden 1995.
Comparing Constitutions. Oxford: Oxford University Press.

Girling, John L. S. 1981. Thailand: Society and Politics. Ithaca: Comell University Press.

Hewison, Kevin 1997. 'The monarchy and democratisation'. In Kevin Hewison (ed.), Political Change in Thailand: Democracy and Participation. London: Routledge: 58-74.

Kusuma Snitwongse 1995. 'Thailand in 1994: the trials of transition'. Asian Survey, 35(1) (January).

McCargo, Duncan 1997a. 'The media and policy advocacy in Thailand'. In Duncan McCargo and Ramaimas Bowra, The Media and Policy Advocacy in Thailand. Bangkok: Institute of Public Policy Studies: 24-40.

McCargo, Duncan 1997b. 'Thailand's political parties: real, authentic, and actual'. In Kevin Hewison (ed.), Political Change in Thailand: Democracy and Participation, London: Routledge: 114-31.

McCargo, Duncan 1997c. Problematising democratisation: the 
Thai case. Working Paper No. 61, Development Research Series. Aalborg University, Denmark.

McCargo, Duncan 1997d. Chamlong Srimuang and the New Thai Politics. London: Hurst.

Naruemon Thabchumpon 1997. 'The role of grassroots NGOs in political reform in Thailand: democracy behind civil society'. Unpublished M.A. diss., Department of Politics, University of Leeds.

Ockey, James 1997. 'Thailand: the crafting of democracy'. Southeast Asian Affairs 1997. Singapore: Institute of Southeast Asian Studies.

Physicians for Human Rights and Asia Watch, 1992. 'Bloody May': Excessive Use of Lethal Force in Bangkok; the Events of May 17-20, 1992. New York.

Prawes Wasi, 1995. Political Reform: the Way out for Thailand. Bangkok: Mo chao ban. (In Thai)

Riggs, Fred W. 1966. Thailand: The Modernisation of a Bureaucratic
Polity. Honolulu: East-West Center Press.

Royal Remarks on Various Occasions, undated (published 1997). Bangkok: Amarin Printing.

Sombat Chantornvong 1993. Thai Elections in Crisis: Problems and Solutions. Bangkok: Kopfai. (In Thai)

Surin Maisrikrod and McCargo, Duncan 1997. 'Electoral poli tics: commercialisation and exclusion', in Kevin Hewison (ed.), Political Change in Thailand: Democracy and Participation, London: Routledge: 13248.

Thai Constitution 1997. Bangkok: Office of the Secretary-General of Parliament. (In Thai)

Vichai Tunsri. 1997. Constitutions of Western Countries and Thailand: a Comparative Legal and Historical Study. Bangkok: Institute of Public Policy Studies (in Thai).

Wilson, David. 1967. Politics in Thailand. Ithaca: Cornell University Press. 